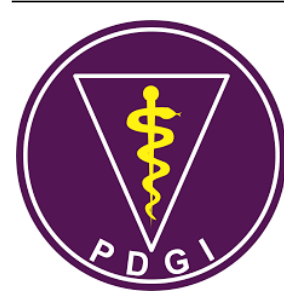

\title{
Dental Visit, Dental Diseases, and Dental Therapist Pattern in The Implementation of NHI at Private Clinics
}

\author{
Afina Hasnasari Heningtyas ${ }^{1 \S}$, Iwan Dewanto ${ }^{1}$ \\ ${ }^{1}$ Department of Public Health Dentistry, Faculty of Medicine and Health Science, Muhammadiyah University of Yogyakarta, Indonesia
}

Received date: January 5, 2019. Accepted date: March 15, 2019. Published date: April 30, 2019.

\section{KEYWORDS \\ dental capitation; dental utilization; pattern of disease; primary clinic; primary dentist}

\begin{abstract}
Introduction: Since 2014 through the National Health Insurance (JKN) program, the pattern of health financing in Indonesia has been changed, in the first level health facilities (FKTP), from the fee for service payment to capitation payments system. Reports from the Public Health Office of Yogyakarta City showed that in 2014 there was an increased in basic dental services in the city of Yogyakarta by $68.01 \%$ from 2013. The Firdaus Pratama Clinic Yogyakarta is a primary clinic with medical and dental services as one of the providers of the JKN program since 2015. Objective: The purpose of this study was to evaluate the implementation of the national health insurance program in dentistry at Firdaus Pratama Clinic, Yogyakarta. Methods: The type of this research was descriptive observational study, with the method used in the form of secondary data observation. Secondary data was obtained through electronic medical records at Firdaus Pratama Clinic. This research was conducted at the Firdaus Pratama Clinic in Yogyakarta which has been working with BPJS since 2015. Results: The number of participants and the number of dental visits at the Firdaus Pratama Clinic continued to increase. The 3 diagnoses in dental services at the Firdaus Pratama Clinic that frequently found in the form of consultation were necrosis of pulp, dental caries, and pulpitis. Conclusion: The category of dental visits at Firdaus Pratama Clinic was high, which found more than $2 \%$ utilization based on the number of participants and dental visits.
\end{abstract}

\footnotetext{
${ }^{\S}$ Corresponding Author

E-mail address: afinahasnasari@gmail.com (Heningtyas AH)
}

\section{DOI: https://doi.org/10.32793/jida.v2i1.354}

Copyright: (02019 Heningtyas AH, Dewanto I. This is an open access article distributed under the terms of the Creative Commons Attribution License, which permits unrestricted use, distribution, and reproduction in any medium provided the original author and sources are credited. 


\section{KATA KUNCI}

dokter gigi primer; kapitasi gigi; klinik pratama; utilisasi kunjungan gigi; pola penyakit

\begin{abstract}
ABSTRAK
Pendahuluan: Sejak tahun 2014 melalui program jaminan kesehatan nasional (JKN), pola pembiayaan kesehatan di Indonesia telah mengalami perubahan, pada fasilitas kesehatan tingkat pertama (FKTP) yaitu dari sistem fee for service menjadi pembayaran kapitasi. Laporan dari Dinas Kesehatan Kota Yogyakarta menunjukkan bahwa pada tahun 2014 terjadi peningkatan pelayanan dasar gigi di Kota Yogyakarta sebesar 68,01\% dari tahun 2013. Klinik Pratama Firdaus Yogyakarta merupakan klinik pratama dengan pelayanan umum dan pelayanan gigi sebagai salah satu provider program JKN sejak tahun 2015 hingga saat ini. Tujuan: Tujuan dari penelitian ini adalah untuk melakukan evaluasi pelaksanaan sistem jaminan kesehatan nasional bidang kedokteran gigi di Klinik Pratama Firdaus. Metode: Jenis penelitian ini adalah penelitian observasional deskriptif dengan metode yang digunakan berupa observasi data sekunder. Data sekunder tersebut diperoleh melalui rekam medis di Klinik Pratama Firdaus yang berupa rekam medis elektronik. Penelitian ini dilakukan di Klinik Pratama Firdaus Propinsi Yogyakarta yang telah bekerja sama dengan badan penyelenggara jaminan sosial (BPJS) Kesehatan sejak tahun 2015. Hasil: Jumlah peserta dan jumlah kunjungan gigi di Klinik Pratama Firdaus terus mengalami peningkatan setiap tahunnya. Tiga diagnosis terbanyak pada pelayanan gigi di Klinik Pratama Firdaus yaitu necrosis of pulp, dental caries, dan pulpitis dengan tindakan terbanyak berupa konsultasi. Kesimpulan: Kunjungan gigi di Klinik Pratama Firdaus termasuk ke dalam kategori tinggi yaitu utilisasi lebih dari $2 \%$ berdasarkan data jumlah peserta dan data kunjungan pasien.
\end{abstract}

\section{PENDAHULUAN}

Saat ini masyarakat cenderung datang ke dokter gigi pada saat ada keluhan saja yang menunjukkan kesadaran masyarakat akan kesehatan gigi dan mulut masih rendah. Rata-rata masyarakat datang ke dokter gigi dalam keadaan gigi yang cukup parah dan memerlukan penanganan lebih lanjut yang akan berdampak pada biaya perawatan yang lebih tinggi. Data dari Riskesdas tahun 2013 menyebutkan bahwa 25,9\% penduduk Indonesia mengalami permasalahan gigi dan mulut. ${ }^{1}$ Di Propinsi Daerah Istimewa (D.I.) Yogyakarta sendiri sebanyak $32,1 \%$ masyarakat mengalami permasalahan gigi dan mulut, namun $31,9 \%$ di antaranya telah menerima perawatan dari tenaga medis gigi (perawat gigi, dokter gigi atau dokter gigi spesialis). Hal ini menunjukkan bahwa sebagian besar permasalahan gigi dan mulut telah dapat ditangani oleh tenaga medis gigi di propinsi D.I. Yogyakarta. $^{2}$

Laporan dari Dinas Kesehatan Kota Yogyakarta menunjukkan bahwa pada tahun 2014 terjadi peningkatan pelayanan dasar gigi di Kota Yogyakarta sebesar 68,01\% dari tahun 2013. Pelayanan dasar gigi tersebut berupa tumpatan gigi tetap dan pencabutan gigi tetap. ${ }^{2}$ Pada tahun 2014 ini juga merupakan tahun dimulainya program Jaminan Kesehatan Nasional (JKN) yang bertujuan menjamin agar peserta memperoleh manfaat pemeliharaan kesehatan dan perlindungan dalam memenuhi kebutuhan dasar kesehatan, termasuk juga kesehatan gigi dan mulut. ${ }^{3}$

Sejak tahun 2014 melalui program JKN, pola pembiayaan kesehatan di Indonesia telah mengalami perubahan, pada fasilitas kesehatan tingkat pertama (FKTP) perubahannya yaitu dari sistem out of pocket yang berupa fee for service, menjadi pembayaran kapitasi. ${ }^{4}$ Hal tersebut menyebabkan terdapat perubahan pembayaran bagi pasien yang datang untuk melakukan pemeriksaan. Pada pembayaran fee for service, dokter mendapatkan pembayaran berdasarkan volume layanan yang dilakukan seperti jumlah perawatan dan tes yang dilakukan, yang artinya pasien akan membayar sesuai dengan perawatan yang diterima. ${ }^{5}$ Pada pembayaran kapitasi, dokter dibayar dengan sejumlah uang tetap di awal untuk setiap pasien yang terdaftar dalam prakteknya dan sebagai imbalan untuk jumlah yang tetap ini, dokter dikontrak dan berkewajiban untuk memberikan pelayanan primer pada jangka waktu tertentu tanpa adanya biaya tambahan. ${ }^{6}$ Hal ini menunjukkan bahwa pasien yang telah mengikuti program JKN berhak memperoleh pelayanan tanpa adanya biaya tambahan, termasuk juga pada pelayanan gigi dan mulut.

Paket pelayanan dasar kesehatan gigi dan mulut yang dapat diterima oleh pasien di FKTP seperti puskesmas, klinik pratama, dan praktek mandiri dokter gigi layanan primer yang ditetapkan oleh pemerintah adalah konsultasi, premedikasi, kegawat-daruratan dental, pencabutan gigi sulung (dengan anestesi topikal dan infiltrasi), pencabutan gigi permanen tanpa penyulit, tumpatan komposit atau Glass Ionomer Cement (GlC), dan skaling atau pembersihan karang gigi satu kali per tahun. ${ }^{7}$ Biaya kapitasi gigi saat ini sesuai dengan ketetapan Pemerintah melalui SK Menkes No. 69 Tahun 2013 adalah $\mathrm{Rp} 2.000$ per orang per bulan. ${ }^{8}$

Klinik Pratama Firdaus Yogyakarta merupakan klinik pratama dengan pelayanan umum dan pelayanan gigi sebagai salah satu provider program JKN sejak tahun 2015 hingga saat ini. Klinik ini berlokasi di daerah 
perkotaan di wilayah Kota Yogyakarta. Berdasarkan fakta-fakta di atas penulis ingin melakukan penelitian tentang evaluasi pelaksanaan sistem jaminan kesehatan nasional bidang kedokteran gigi di Klinik Pratama Firdaus.

\section{BAHAN DAN METODE}

Penelitian ini dilakukan pada tahun 2018 bertempat di Klinik Pratama Firdaus Yogyakarta. Jenis penelitian ini adalah penelitian observasional deskriptif dengan metode yang digunakan berupa observasi klinis dan observasi data sekunder. Data sekunder yang diamati berupa data jumlah peserta BPJS, data kunjungan gigi peserta BPJS, data jumlah penyakit gigi dan mulut, serta data tindakan gigi dan mulut pada tahun 2015 - 2017 di Klinik Pratama Firdaus Yogyakarta. Data sekunder tersebut diperoleh melalui rekam medis (RM) di Klinik Pratama Firdaus yang berupa RM elektronik. Data utilisasi kunjungan diperoleh melalui perhitungan jumlah kunjungan gigi dibagi dengan jumlah peserta dalam periode waktu yang sama dikalikan dengan $100 \%$. Hasil dari perhitungan utilisasi dapat dikategorikan menjadi kategori rendah $(<2 \%)$, kategori baik $(2 \%)$, dan kategori tinggi (>2\%). Penelitian ini menjamin kerahasiaan data pasien dengan cara menggunakan database sistim IT di Klinik Pratama Firdaus yang hanya berupa nomor RM, tanpa melihat nama dan alamat pasien.

\section{HASIL}

Penelitian mengenai evaluasi pelaksanaan sistem jaminan kesehatan nasional bidang kedokteran gigi telah dilakukan di Klinik Pratama Firdaus Yogyakarta. Klinik Pratama Firdaus telah bekerja sama dengan BPJS Kesehatan sejak bulan Agustus tahun 2015 hingga saat ini. Klinik Pratama Firdaus memiliki dokter gigi yang berjumlah 5 dokter gigi. Klinik Pratama Firdaus membuka jam pelayanan gigi selama 7 jam yaitu dari pukul 12.30-19.30 yang terbagi atas 2 sesi dengan masing-masing sesi berlangsung selama 3.5 jam dengan 1 dokter gigi yang berjaga di setiap sesinya. Sesi pertama yaitu dari pukul 12.30-16.00 dan sesi kedua yaitu dari pukul 16.00-19.30. Alat dan bahan kedokteran gigi di Klinik Pratama Firdaus sudah cukup lengkap dengan tersedianya peralatan tambal gigi, cabut gigi, perawatan pulpa, pembersihan karang gigi, dan alat dan bahan untuk pembuatan gigi tiruan. Selain melayani pasien BPJS, Klinik Pratama firdaus juga melayani perawatan pasien gigi umum atau yang non-BPJS dengan alat dan bahan yang sama dengan pasien BPJS. Dalam hal ini berarti Klinik Pratama Firdaus tidak membeda-bedakan pasien baik itu pasien umum atau pasien BPJS. Hasil yang diperoleh dapat disajikan sebagai berikut.

Tabel 1 menjelaskan bahwa jumlah peserta BPJS Kesehatan di Klinik Pratama Firdaus Yogyakarta setiap bulannya terus mengalami peningkatan dari tahun 2015 hingga tahun 2017. Di awal kerja sama yaitu Bulan Agustus 2015, jumlah peserta BPJS Kesehatan adalah sebesar 769 peserta dan di akhir tahun 2017 jumlah peserta BPJS Kesehatan adalah sebesar 8.517 peserta pada bulan Desember 2017. Tabel 2 dan Gambar 1 menunjukkan bahwa jumlah kunjungan gigi mengalami peningkatan setiap tahunnya seiring dengan penambahan jumlah peserta BPJS di Klinik Pratama Firdaus, namun jumlah kunjungan setiap bulannya masih mengalami kenaikan dan penurunan. Jumlah kunjungan gigi terbanyak yaitu pada bulan Oktober tahun 2017 sebesar 286 kunjungan.

Tabel 3 menunjukkan bahwa angka utilisasi kunjungan gigi di Klinik Pratama Firdaus juga mengalami peningkatan dan penurunan seiring dengan jumlah kunjungan gigi. Jumlah utilisasi kunjungan di Klinik Pratama Firdaus berkisar antara 2-4\%. Utilisasi merupakan tingkat pemanfaatan pelayanan kesehatan. Rumus utilisasi adalah jumlah kunjungan dibagi dengan jumlah peserta dalam periode waktu yang sama dikalikan dengan $100 \%$. Utilisasi kunjungan terbanyak yaitu pada bulan Maret tahun 2017 sebesar 3.61\% yang artinya sebanyak $3.61 \%$ peserta JKN memanfaatkan pelayanan gigi pada bulan tersebut.

Tabel 4 menunjukkan bahwa tindakan gigi yang paling banyak dilakukan di Klinik Pratama Firdaus tahun 2015-2017 adalah konsultasi. Jumlah tindakan konsultasi di tahun 2017 mencapai lebih dari 1.000 kunjungan yaitu sebesar 1.619 kunjungan. Tindakan gigi lain yang banyak dilakukan yaitu tumpat semen ionomer kaca (SIK), devitalisasi pulpa, dan tumpat resin komposit (RK).

Tabel 5 menunjukkan bahwa tiga diagnosis penyakit gigi terbanyak dari tahun 2015-2017 di Klinik Pratama Firdaus adalah necrosis of pulp, caries of dentin, dan pulpitis. Hal ini menunjukkan bahwa masyarakat masih banyak yang datang ke dokter gigi dalam kondisi gigi yang sakit. Jumlah kunjungan masyarakat yang datang ke dokter gigi hanya untuk memeriksakan kondisi gigi dan mulutnya tanpa keluhan atau termasuk ke dalam diagnosis dental examination tidak sampai 50 kunjungan.

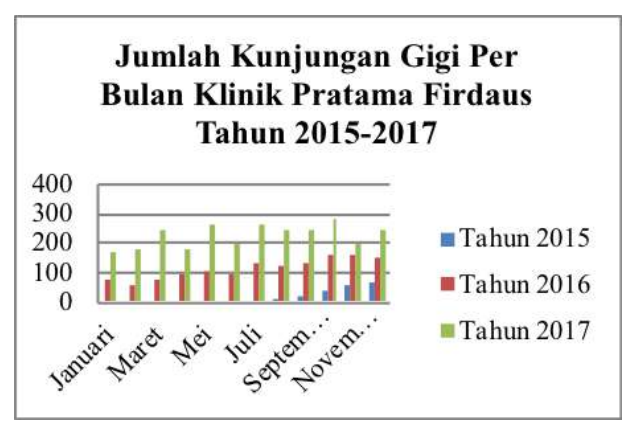

Gambar 1. Jumlah Kunjungan Gigi Per Bulan di Klinik Pratama Firdaus Tahun 2015-2017 
Tabel 1. Jumlah Peserta BPJS Kesehatan di Klinik Pratama Firdaus Tahun 2015-2017

\begin{tabular}{lccc}
\hline \multirow{2}{*}{ Bulan } & \multicolumn{3}{c}{ Tahun } \\
\cline { 2 - 4 } & 2015 & 2016 & 2017 \\
\hline Januari & - & 2965 & 6362 \\
Februari & - & 3288 & 6600 \\
Maret & - & 3621 & 6786 \\
April & - & 3953 & 7061 \\
Mei & - & 4240 & 7276 \\
Juni & - & 4560 & 7495 \\
Juli & - & 4816 & 7495 \\
Agustus & 769 & 5060 & 7880 \\
September & 1477 & 5215 & 8001 \\
Oktober & 1703 & 5538 & 8284 \\
November & 1958 & 5854 & 8348 \\
Desember & 2687 & 6169 & 8517 \\
\hline
\end{tabular}

Tabel 2. Jumlah kunjungan gigi per bulan di Klinik Pratama Firdaus Yogyakarta Tahun 2015-2017

\begin{tabular}{lccc}
\hline \multirow{2}{*}{ Bulan } & \multicolumn{3}{c}{ Tahun } \\
\cline { 2 - 4 } & 2015 & 2016 & 2017 \\
\hline Januari & - & 75 & 165 \\
Februari & - & 61 & 183 \\
Maret & - & 79 & 245 \\
April & - & 93 & 179 \\
Mei & - & 107 & 262 \\
Juni & - & 91 & 200 \\
Juli & - & 135 & 260 \\
Agustus & 3 & 121 & 248 \\
September & 20 & 135 & 248 \\
Oktober & 41 & 164 & 286 \\
November & 60 & 159 & 202 \\
Desember & 67 & 150 & 241 \\
\hline
\end{tabular}

Tabel 3. Utilisasi Kunjungan Gigi di Klinik Pratama Firdaus Tahun 2015-2017

\begin{tabular}{lccc}
\hline \multirow{2}{*}{ Bulan } & \multicolumn{3}{c}{ Tahun } \\
\cline { 2 - 4 } & 2015 & 2016 & 2017 \\
\hline Januari & - & $2.53 \%$ & $2.59 \%$ \\
Februari & - & $1.86 \%$ & $2.77 \%$ \\
Maret & - & $2.18 \%$ & $3.61 \%$ \\
April & - & $2.35 \%$ & $2.54 \%$ \\
Mei & - & $2.52 \%$ & $3.60 \%$ \\
Juni & - & $2.00 \%$ & $2.67 \%$ \\
Juli & - & $2.80 \%$ & $3.47 \%$ \\
Agustus & $0.39 \%$ & $2.39 \%$ & $3.15 \%$ \\
September & $1.35 \%$ & $2.59 \%$ & $3.10 \%$ \\
Oktober & $2.41 \%$ & $2.96 \%$ & $3.45 \%$ \\
November & $3.06 \%$ & $2.72 \%$ & $2.42 \%$ \\
Desember & $2.49 \%$ & $2.43 \%$ & $2.83 \%$ \\
\hline
\end{tabular}

Tabel 4. Diagnosis Gigi Terbanyak di Klinik Pratama Firdaus Tahun 2015-2017

\begin{tabular}{|c|c|c|c|c|c|}
\hline \multirow{2}{*}{$\begin{array}{l}\text { Kode } \\
\text { ICD X }\end{array}$} & \multirow{2}{*}{ Diagnosis } & \multicolumn{3}{|c|}{ Tahun } & \multirow{2}{*}{ Total } \\
\hline & & 2015 & 2016 & 2017 & \\
\hline K04.1 & $\begin{array}{l}\text { Necrosis of pulp } \\
\text { disertai lesi } \\
\text { periapikal pada } \\
\text { gigi }\end{array}$ & 48 & 284 & 455 & 787 \\
\hline K02.1 & Caries of dentin & 28 & 110 & 165 & 303 \\
\hline K04.0 & Pulpitis & 16 & 125 & 206 & 347 \\
\hline K03.6 & $\begin{array}{l}\text { Deposits } \\
\text { [accretions] on } \\
\text { teeth }\end{array}$ & 6 & 21 & 13 & 40 \\
\hline
\end{tabular}

Other and unspecified

$\begin{array}{llllll}\text { K04.9 diseases of pulp } & 5 & 0 & 15 & 20\end{array}$ and periapical tissues

\begin{tabular}{|c|c|c|c|c|c|}
\hline K05.0 & Acute gingivitis & 5 & 17 & 17 & 39 \\
\hline K08.2 & $\begin{array}{l}\text { Atrophy of } \\
\text { edentulous } \\
\text { alveolar ridge }\end{array}$ & 5 & 7 & 12 & 24 \\
\hline Z01.2 & $\begin{array}{l}\text { Dental } \\
\text { Examination }\end{array}$ & 4 & 11 & 47 & 62 \\
\hline K00.6 & $\begin{array}{l}\text { Disturbances in } \\
\text { tooth eruption }\end{array}$ & 4 & 31 & 67 & 102 \\
\hline K03.1 & Abrasi gigi & 4 & 13 & 68 & 85 \\
\hline K01.1 & Impacted teeth & 1 & 33 & 73 & 107 \\
\hline K06.8 & $\begin{array}{l}\text { Other specified } \\
\text { disorders of } \\
\text { gingiva and } \\
\text { edentulous } \\
\text { alveolar ridge }\end{array}$ & 0 & 29 & 37 & 66 \\
\hline K05.3 & $\begin{array}{l}\text { Chronic } \\
\text { periodontitis }\end{array}$ & 0 & 24 & 27 & 51 \\
\hline K05.1 & $\begin{array}{l}\text { Chronic } \\
\text { gingivitis }\end{array}$ & 0 & 20 & 12 & 32 \\
\hline K04.7 & $\begin{array}{l}\text { Periapical } \\
\text { abscess without } \\
\text { sinus }\end{array}$ & 1 & 18 & 58 & 77 \\
\hline K08.3 & $\begin{array}{l}\text { Retained dental } \\
\text { root }\end{array}$ & 0 & 8 & 62 & 70 \\
\hline
\end{tabular}


Tabel 5. Tindakan Gigi Terbanyak di Klinik Pratama Firdaus Tahun 2015-2017

\begin{tabular}{lcccc}
\hline \multirow{2}{*}{ Tindakan } & \multicolumn{3}{c}{ Tahun } & Total \\
\cline { 2 - 4 } & 2015 & 2016 & 2017 & \\
\hline Konsultasi & 33 & 461 & 1125 & 1619 \\
$\begin{array}{l}\text { Tumpat SIK } \\
\text { Pemeriksaan }\end{array}$ & 33 & 146 & 214 & 393 \\
$\begin{array}{l}\text { lengkap } \\
\text { Ekstraksi }\end{array}$ & 22 & 22 & 0 & 44 \\
$\begin{array}{l}\text { permanen } \\
\text { infiltasi }\end{array}$ & 19 & 44 & 173 & 236 \\
$\begin{array}{l}\text { Scalling uss } \\
\text { Tumpat RK }\end{array}$ & 13 & 98 & 93 & 204 \\
$\begin{array}{l}\text { Devitalisasi } \\
\text { pulpa }\end{array}$ & 7 & 71 & 189 & 267 \\
$\begin{array}{l}\text { Trepanasi } \\
\text { Kaping pulpa }\end{array}$ & 7 & 29 & 52 & 88 \\
$\begin{array}{l}\text { Ekstraksi } \\
\text { decidui topical }\end{array}$ & 3 & 40 & 70 & 113 \\
$\begin{array}{l}\text { Ekstraksi } \\
\text { desidui }\end{array}$ & 2 & 28 & 57 & 87 \\
$\begin{array}{l}\text { infiltrasi } \\
\begin{array}{l}\text { Tumpatan } \\
\text { sementara }\end{array}\end{array}$ & 0 & 12 & 69 & 81 \\
\hline
\end{tabular}

\section{PEMBAHASAN}

Jumlah kunjungan gigi pada Klinik Pratama Firdaus terus meningkat seiring dengan peningkatan jumlah peserta setiap tahunnya. Hal ini kemungkinan disebabkan karena Klinik Pratama Firdaus membuka jam pelayanan gigi pada siang hingga malam hari dimana masyarakat yang bekerja dapat melakukan perawatan gigi setelah pulang bekerja di sore hari sehingga menarik masyarakat untuk terdaftar pada Klinik Pratama Firdaus. Karakteristik daerah penelitian yang berada di wilayah perkotaan dimana sebagian besar masyarakat merupakan pekerja memiliki kecenderungan untuk untuk memeriksakan kesehatannya pada waktu di luar jam kerja. ${ }^{9}$

Apabila dilihat lebih lanjut terjadi peningkatan utilisasi kunjungan gigi dimana pada tahun 2017 menjadi berkisar antara 2,3 - 3,5\%. Angka utilisasi gigi yang ideal minimal yaitu 2\%. Angka utilisasi gigi lebih dari 3\% menunjukkan pelayanan kesehatan gigi dan mulut berada dalam kategori tinggi. ${ }^{4}$ Apabila kunjungan gigi tinggi maka dapat menyebabkan ketidakseimbangan risiko dan pembiayaan dalam pelayanan kesehatan gigi dan mulut. ${ }^{9}$ Dalam suatu teori ekonomi disebutkan bahwa orangorang yang memilih metode pembayaran kapitasi dibandingkan dengan fee for service merupakan orangorang dengan risiko yang lebih tinggi yang membutuhkan perawatan gigi. ${ }^{10}$ Utilisasi kunjungan gigi tinggi selain dapat disebabkan karena kebutuhan perawatan masyarakat yang tinggi, juga dapat disebabkan karena kepuasan pasien terhadap pelayanan dokter gigi. Suatu studi menunjukkan bahwa kepuasan pasien terutama dalam pelayanan gigi merupakan salah satu aspek yang penting dalam kualitas pelayanan dan dapat menentukan utilisasi ke depannya ${ }^{11}$, namun variabel terkait kepuasan pasien tidak diukur dalam penelitian ini. Pada penelitian ini diketahui bahwa tiga diagnosis terbanyak pada pelayanan gigi di Klinik Pratama Firdaus yaitu necrosis of pulp, dental caries, dan pulpitis. Diagnosis tersebut tentunya memerlukan perawatan dengan biaya yang tinggi seperti tumpatan gigi, ekstraksi gigi, dan perawatan pulpa. Klinik pratama yang mengelola sendiri seluruh pengelolaan keuangannya termasuk yaitu kebutuhan BMHP (Bahan Medis Habis Pakai) dan alat-alat kedokteran gigi, akan menderita kerugian apabila banyak pasien yang datang untuk melakukan tindakan perawatan gigi.

Diagnosis-diagnosis tersebut juga menunjukkan bahwa masyarakat masih cenderung datang memeriksakan kondisi kesehatan gigi dan mulutnya apabila ada keluhan rasa sakit. Masih banyak masyarakat yang belum beranggapan bahwa kesehatan gigi dan mulut merupakan suatu permasalahan kesehatan yang tidak kalah pentingnya dengan kesehatan umum. Masyarakat beranggapan bahwa ketika terdapat masalah kesehatan gigi namun masih dapat melakukan aktivitas sehari-hari, maka masyarakat akan lebih mengutamakan bekerja untuk mendapatkan penghasilan dibandingkan untuk memeriksakan kesehatan giginya ke dokter gigi.

Penelitian yang dilakukan oleh Straind, dkk. pada tahun 2015 menyebutkan bahwa perubahan pola pembiayaan kesehatan menjadi kapitasi dapat menyebabkan perubahan kebiasaan masyarakat menjadi ke arah yang lebih baik yaitu menjaga kesehatan gigi dan mulut. ${ }^{12}$ Pada penelitian ini diketahui bahwa masih sedikit masyarakat yang datang hanya untuk memeriksakan kondisi kesehatan gigi dan mulutnya saja tanpa dilakukan tindakan, yang tercermin pada kunjungan untuk diagnosa dental examination atau pemeriksaan gigi yang rendah.

Tindakan gigi yang banyak dilakukan oleh dokter gigi di Klinik Pratama Firdaus yaitu konsultasi yang berjumlah 1.125 tindakan di tahun 2017. Apabila diperhatikan lebih lanjut maka terdapat ketidaksamaan antara data-data diagnosis dan juga data-data tindakan. Diagnosis terbanyak merupakan penyakit-penyakit gigi dan mulut yang memerlukan tindakan perawatan, namun tindakan gigi terbanyak justru hanya konsultasi tanpa melakukan perawatan. Hal ini kemungkinan tindakan 
konsultasi pada pelayanan gigi di Klinik Pratama Firdaus mencakup medikasi dan atau rujukan. Artinya, apabila ada pasien yang membutuhkan rujukan ke fasilitas kesehatan tingkat lanjut sementara tidak dilakukan tindakan perawatan yang lain, maka dokter gigi di Klinik Pratama Firdaus akan memilih konsultasi sebagai pilihan tindakan perawatan. Perlu dilakukan persamaan persepsi oleh dokter gigi di Klinik Pratama Firdaus terkait diagnosis dan tindakan pada rekam medis elektronik agar diagnosis dan tindakan yang dipilih seragam dan tidak menimbulkan bias. Pada pembayaran kapitasi dengan pendekatan managed care, terdapat fungsi gatekeeper dimana setiap dokter menentukan apakah rujukan ke spesialis gigi diperlukan atau tidak. ${ }^{13}$ Salah satu risiko dari pembayaran kapitasi yaitu dapat menyebabkan meningkatnya angka rujukan fasilitas kesehatan tingkat pertama ke tingkat yang lebih tinggi atau tingkat spesialis, sehingga ini dapat menyebabkan efisiensi biaya perawatan yang rendah. Dengan mengirimkan pasien ke spesialis, dokter di layanan primer tidak perlu melakukan perawatan, namun tetap mendapat biaya kapitasi. ${ }^{6,14}$

Hasil penelitian menunjukkan bahwa terdapat peningkatan jumlah peserta setiap tahunnya di Klinik Pratama Firdaus, maka ke depannya jumlah peserta BPJS di Klinik Pratama Firdaus juga masih dapat terus meningkat. Jumlah peserta yang meningkat dapat meningkatkan jumlah kunjungan gigi di Klinik Pratama Firdaus. Klinik Pratama Firdaus seharusnya mulai dapat melakukan tindakan promotif dan preventif kesehatan gigi untuk meningkatkan kunjungan sehat dan menurunkan kunjungan sakit. Pasien yang datang dalam kondisi gigi yang sehat tentu tidak membutuhkan biaya perawatan yang tinggi. Pembayaran kapitasi memperkenalkan insentif bagi dokter untuk memenuhi kebutuhan kesehatan lebih banyak melalui pencegahan penyakit dan bukannya lebih banyak pada perawatan. ${ }^{15}$

\section{KESIMPULAN}

Kunjungan gigi di Klinik Pratama Firdaus termasuk ke dalam kategori tinggi yaitu utilisasi kunjungan gigi lebih dari $2 \%$. Mayoritas pasien gigi yang datang ke Klinik Pratama Firdaus dalam kondisi sakit yang memerlukan perawatan di klinik maupun rujukan ke tingkat spesialis.

\section{KONFLIK KEPENTINGAN}

Tidak ada konflik kepentingan dalam penelitian ini.

\section{DAFTAR PUSTAKA}

1. Indonesia. Badan Penelitian dan Pengembangan
Kesehatan. Riset kesehatan dasar 2013. Jakarta: Kementerian Kesehatan RI; 2013.

2. Indonesia. Dinas Kesehatan Kota Yogyakarta. Profil kesehatan tahun 2015 Kota Yogyakarta (data tahun 2014). Yogyakarta; 2015.

3. Indonesia. Pemerintah RI. Undang-Undang RI No.40 Tahun 2004. Sistem Jaminan Sosial Nasional. Jakarta. 2004.

4. Dewanto I, Lestari NI. Panduan pelaksanaan pelayanan kesehatan gigi dan mulut dalam system jaminan kesehatan nasional (guide to the implementation of oral health service in a national health insurance system. 1 st ed. Jakarta: PB PDGI; 2014.

5. Adida E, Mamani H, Nassiri S. Bundled payment vs. fee-for-service: impact of payment scheme on performance. Manage Sci. 2015;63(5):1-19.

6. Leger PT. Physician payment mechanisms: An overview of policy options for Canada. Ottawa (CA): Canadian Health Services Research Foundation; 2011.

7. PB PDGI. Surat Edaran Pengurus Besar Persatuan Dokter Gigi Indonesia tentang pelayanan kesehatan gigi dalam Sistem Jaminan Kesehatan Nasional. Jakarta: PB PDGI; 2013.

8. Indonesia Regulation of the Minister of Health, Number 069/Menkes/PER/XI/2013 on Capitation of Health Insurance system.

9. Darmawan IR, Thabrany H. Refleksi implementasi Jaminan Kesehatan Nasional pada pelayanan kedokteran gigi di fasilitas kesehatan tingkat pertama Kota Tangerang tahun 2017. Jurnal Kebijakan Kesehatan Indonesia. 2017;6(3):174-183.

10. Andas CA, Hakeberg M. Who chooses prepaid dental care? A baseline report of a prospective observational study. BMC Oral Health. 2014;14:146.

11. Patel R, Eaton KA, Garcia A, Rincon V, Adams L, Brooks J. Factors influencing dental practitioner performance: a summary of a recent literature review. OHDM. 2011. 10(3): 119-130.

12. Strand J, Andas CA, Boman UW, Hakeberg M, Tidefors I. A new capitation payment system in dentistry: the patient's perspective. Community Dental Health. 2015;32:83-88.

13. The national insurance guide. St. Louis (US): American Association of Orthodontists; 2008.

14. Hariyanti M. Evaluasi pelaksanaan program dokter gigi keluarga askes di Kabupaten Kudus [Tesis]. Yogyakarta: Universitas Gajah Mada. 2012.

15. Hill H, Birch S, Tickle M, McDonald R, Donaldson $\mathrm{S}$, O'caroland D, et al. Does capitation affect the delivery of oral healthcare and access to services? Evidence from a pilot contact in Northern Ireland. BMC Health Service Research. 2017;17:175. 